\title{
Structure and Site Evolution of Iron Oxide Catalyst Precursors during the Fischer-Tropsch Synthesis
}

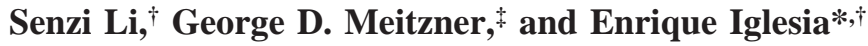 \\ Department of Chemical Engineering, University of California, Berkeley, California 94720-1462, and \\ Edge Analytical, Inc., Middleton, Wisconsin 53562
}

Received: January 24, 2001; In Final Form: March 22, 2001

\begin{abstract}
The contacting of $\mathrm{Fe}$ oxide precursors with synthesis gas $\left(\mathrm{H}_{2} / \mathrm{CO}\right.$ mixtures) leads to structural and chemical changes and to the formation of the active sites required for the Fischer-Tropsch synthesis (FTS). The local structure and oxidation state of the starting $\mathrm{Fe}_{2} \mathrm{O}_{3}$ precursors promoted by $\mathrm{Cu}$ and/or $\mathrm{K}$ were probed using in situ X-ray absorption spectroscopy during these processes. The activation of these precursors occurs via reduction to $\mathrm{Fe}_{3} \mathrm{O}_{4}$ followed by carburization to form $\mathrm{FeC}_{x}$. FTS reaction rates increased markedly during the initial stages of carburization, suggesting that the conversion of near-surface layers of $\mathrm{Fe}_{3} \mathrm{O}_{4}$ to $\mathrm{FeC}_{x}$ is sufficient for the formation of the required active sites. Thus, bulk structural probes, and any ex situ techniques without concurrent measurements of the products evolved during activation and FTS, can lead to misleading structurefunction relations. The initial rate of carburization and the extent of carburization and the FTS rate at steadystate were higher for $\mathrm{Fe}_{2} \mathrm{O}_{3}$ precursors containing either $\mathrm{Cu}$ or $\mathrm{K}$. These effects were stronger when both promoters were present. $\mathrm{K}$ and $\mathrm{Cu}$ provide $\mathrm{CO}$ and $\mathrm{H}_{2}$ activation sites, which lead to the nucleation of multiple carbide regions on $\mathrm{Fe}$ oxide surfaces. The larger number of nucleation sites leads to higher initial carburization rates and to smaller $\mathrm{FeC}_{x}$ crystallites. These smaller crystallites, in turn, provide higher active surface areas, shorter bulk diffusion distances, more complete carburization of $\mathrm{Fe}_{2} \mathrm{O}_{3}$ precursors, and higher steady-state FTS rates. These effects of $\mathrm{K}$ and $\mathrm{Cu}$ on the number of available $\mathrm{FeC}_{x}$ sites were confirmed by titrating surface sites using $\mathrm{CO}$ after FTS reactions. It appears that $\mathrm{K}$ and $\mathrm{Cu}$ act predominantly as structural promoters, which increase the surface area of the active $\mathrm{FeC}_{x}$ phases. Chemical promotion of catalytic rates by these additives appears not to be required to explain the observed FTS rate enhancements in the presence of $\mathrm{K}$ or $\mathrm{Cu}$. These structural promotion effects of $\mathrm{Cu}$ and $\mathrm{K}$ account for the apparent but non-causal correlation between bulk $\mathrm{FeC}_{x}$ contents and FTS rates at steady-state, even though the carburization of only near-surface regions in bulk $\mathrm{Fe}_{3} \mathrm{O}_{4}$ is sufficient to achieve steady-state FTS turnover rates.
\end{abstract}

\section{Introduction}

The Fischer-Tropsch synthesis (FTS) is an attractive route for the production of clean transportation fuels and high molecular weight hydrocarbons from synthesis gas. ${ }^{1}$ Fe-based catalysts are often used for this reaction because of their low cost, flexible product distribution, and ability to use coal-derived synthesis gas with low $\mathrm{H}_{2} / \mathrm{CO}$ ratios. $^{2} \mathrm{Ru}$ and $\mathrm{Co}$ are also effective FTS catalysts. ${ }^{3,4}$ Recently, Co-based catalysts have become an accepted compromise between cost and productivity for the synthesis of clean diesel fuels. Fe-based catalysts complement this product slate by providing higher selectivity to olefins and oxygenates, which are useful as precursors to petrochemicals and to gasoline.

Several $\mathrm{Fe}$ phases, including $\alpha-\mathrm{Fe},{ }^{5} \mathrm{Fe}_{3} \mathrm{O}_{4},{ }^{6,7} \theta-\mathrm{Fe}_{3} \mathrm{C},{ }^{8} \epsilon^{\prime}-$ $\mathrm{Fe}_{2.2} \mathrm{C},{ }^{9} \chi-\mathrm{Fe}_{5} \mathrm{C}_{2},{ }^{10}$ and $\mathrm{Fe}_{7} \mathrm{C}_{3}{ }^{11}$ have been detected in freshly activated or used Fe-based FTS catalysts. Most of these phases have been proposed at various times to be the active species for FTS reactions. The relative abundance of these phases depends on reaction conditions. Even after many ex situ characterization studies, the composition of Fe-based FTS catalysts during reaction and the identity of the active phase

\footnotetext{
* To whom correspondence should be addressed [iglesia@ cchem.berkeley.edu].

University of California.

Edge Analytical, Inc.
}

remain controversial. Fe-based catalysts have been investigated by Mössbauer spectroscopy, ${ }^{10,12}$ but the time resolution of Mössbauer spectroscopy ( $>1 \mathrm{~h}$ for typical samples) precludes its use for in situ transient measurements during initial phase transformations. Also, Mössbauer spectroscopy is sensitive only to the recoil-free fraction, which depends on the structure of the Fe-containing phase. This recoil-free fraction must be accurately measured as a function of temperature for precise structural assessments using Mössbauer spectroscopy. X-ray diffraction (XRD) cannot detect inorganic structures without long-range periodicity; as a result, it is not sensitive to amorphous or well-dispersed Fe species, which tend to account for a large fraction of the available surface area and of the active sites required. X-ray photoelectron spectroscopy (XPS) ${ }^{7,13}$ has been used to examine catalytic solids before and after reaction, but it cannot be used during FTS. It requires quenching and catalyst cleansing procedures that influence the state of the surface layers meant to be probed by XPS. Recent highresolution transmission electron microscopy (HRTEM) studies have addressed the active phase of working Fe catalysts after different activation and reaction treatments; these studies have provided useful and novel insights about the nature of the working Fe catalysts. ${ }^{13,14}$ However, none of these measurements were performed during reaction or even within the FTS reactor. Therefore, the relevant catalytic surfaces may have become 
restructured or contaminated, even with careful handling and controlled passivation, as a result of the indispensable quenching and cleansing procedures.

X-ray absorption spectroscopy (XAS) can probe the local structure of inorganic structures, even as catalytic reactions occur, by using in situ spectroscopic cells with realistic and well-defined hydrodynamics. The X-ray absorption near-edge spectrum (XANES) is sensitive to the oxidation state and to the symmetry of the absorber atom. ${ }^{15}$ Comparisons between these features and those in compounds with known local structure can be used to quantify the fraction of each absorber present within each type of local coordination environment using principal component analysis (PCA) ${ }^{16}$ and linear combination ${ }^{17}$ methods. The region beyond the absorption edge contains oscillations in absorbance, which arise from the scattering of the emitted photoelectrons by the atoms surrounding the absorber. This extended X-ray absorption fine structure (EXAFS) region of the spectrum contains information about the identity and the location of neighboring atoms coordinated to the absorber directly or through other atoms. ${ }^{15}$ Therefore, X-ray absorption methods are ideally suited for in situ characterization of Fe-based FTS catalysts. We are not aware of its previous use for the structural characterization of Fe catalysts during FTS. Several reaction cells have been reported previously for in situ XAS measurements. ${ }^{18,19}$ Here, we report a cell design based on modifications of one of these previously described cells ${ }^{19}$ and use it to probe the local structure of Fe catalysts derived from $\mathrm{Fe}_{2} \mathrm{O}_{3}$ precursors during FTS. This study focuses on the evolution of the $\mathrm{Fe}_{2} \mathrm{O}_{3}$ component in the precursor materials during FTS reactions, on the effect of various promoters $(\mathrm{Cu}$, $\mathrm{K}$ ), and on the extent and rate of structural transformations occurring as $\mathrm{Fe}$ oxide catalyst precursors activate during contact with synthesis gas and as FTS reactions approach steady-state.

\section{Experimental Section}

X-ray Absorption Sample Preparation. Fe K-edge X-ray absorption spectra were measured for reference compounds with known local structures and for catalyst precursors consisting of $\mathrm{Fe}-\mathrm{K}-\mathrm{Cu}$ oxides $(\mathrm{K} / \mathrm{Fe}=0.02, \mathrm{Cu} / \mathrm{Fe}=0.01)$ during their reduction and carburization in $\mathrm{CO}$ and in synthesis gas. $\mathrm{Fe}_{2} \mathrm{O}_{3}$ (Alfa AESAR, 99.998\%), $\mathrm{Fe}_{3} \mathrm{O}_{4}$ (Alfa AESAR, 99.997\%), and FeO (Alfa AESAR, 99.5\%) were used as reference crystalline oxides. $\mathrm{Fe}_{3} \mathrm{C}$, which can form during FTS reactions, was prepared by temperature-programmed reaction $(0.167 \mathrm{~K} / \mathrm{s})$ of $\mathrm{Fe}_{2} \mathrm{O}_{3}$ up to $973 \mathrm{~K}$ using $\mathrm{CO}$ (Matheson, 99.99\%, $107 \mathrm{~mol}$ of $\mathrm{CO} / \mathrm{mol}$ of $\mathrm{Fe} \mathrm{h}$ ) as the reduction and carburization agent. ${ }^{20}$ The resulting $\mathrm{Fe}_{3} \mathrm{C}$ powder was passivated in flowing $1 \% \mathrm{O}_{2} /$ $\mathrm{He}$ (Matheson, $99.999 \%, 0.05 \mathrm{~mol} / \mathrm{h}$ ) at room temperature (RT) for $1 \mathrm{~h}$ before removing the sample from the synthesis cell. $\mathrm{X}$-ray diffraction measurements confirmed the exclusive presence of $\mathrm{Fe}_{3} \mathrm{C}$ in this sample.

The $\mathrm{Fe}_{2} \mathrm{O}_{3}$ used for in situ XAS measurements was prepared by precipitation from an aqueous solution of $\mathrm{Fe}\left(\mathrm{NO}_{3}\right)_{3}$ (Aldrich, $99.99 \%, 3.0 \mathrm{M}$ ) with $\left(\mathrm{NH}_{4}\right)_{2} \mathrm{CO}_{3}$ (Aldrich, $\left.99.9 \%, 1 \mathrm{M}\right)$ at 353 $\mathrm{K}$ and a constant $\mathrm{pH}$ of 7.0. The precipitate was dried at $393 \mathrm{~K}$ overnight and treated in dry air at $643 \mathrm{~K}$ for $4 \mathrm{~h}$. These oxide precursors were impregnated with aqueous solutions of $\mathrm{K}_{2} \mathrm{CO}_{3}$ (Aldrich, 99.99\%,) and/or $\mathrm{Cu}\left(\mathrm{NO}_{3}\right)_{2}$ (Aldrich, 99.99\%) to incipient wetness in order to give $\mathrm{K} / \mathrm{Fe}$ and $\mathrm{Cu} / \mathrm{Fe}$ atomic ratios of 0.02 and 0.01 , respectively. These compositions were found to give the best catalytic performance in the Fischer-Tropsch synthesis. ${ }^{21}$

All samples used in spectroscopic measurements were diluted to 10 wt \% Fe using graphite powder (Alfa AESAR, 99.9995\%,
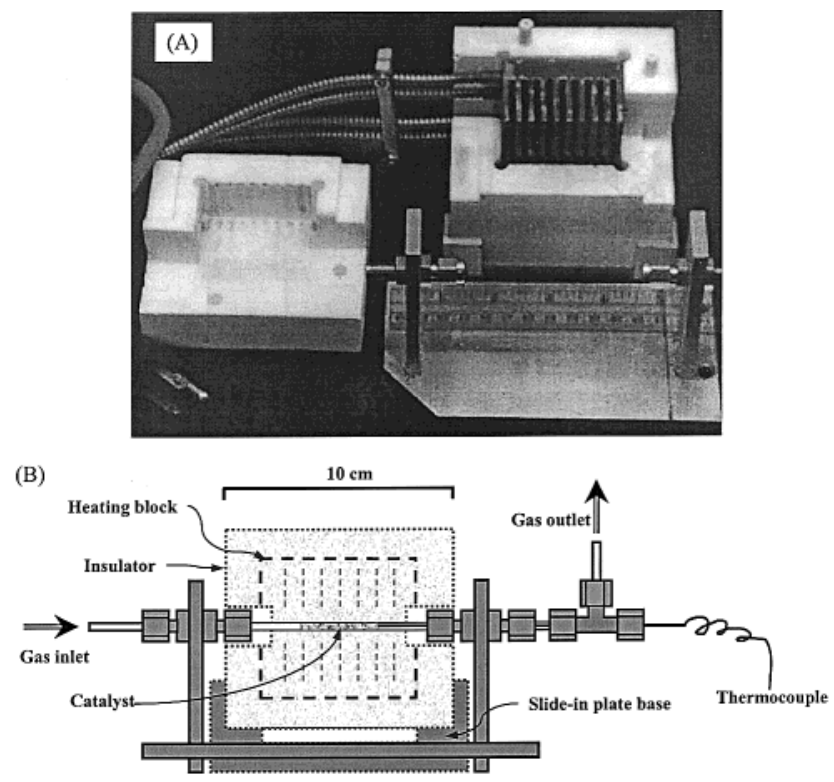

(C)

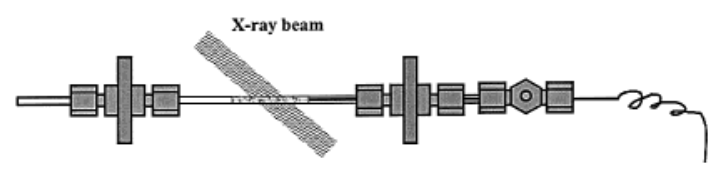

Figure 1. X-ray absorption cell: (A) picture; (B) front view; (C) top view with the heating unit removed.

$S_{\mathrm{g}}<1 \mathrm{~m}^{2} / \mathrm{g}$ ), pressed at $10 \mathrm{MPa}$, sieved to retain $180-250 \mu \mathrm{m}$ particles, and placed within a quartz capillary cell. ${ }^{22}$ The inertness of graphite was tested by flowing $\mathrm{H}_{2}$ over $\mathrm{Fe}$ oxides mixed with graphite up to $873 \mathrm{~K}$ without any detectable formation of $\mathrm{FeC}_{x}$. Also, no carbon oxide products were detected by mass spectrometry, indicating that neither $\mathrm{FeO}_{x}$ nor the $\mathrm{Fe}$ metal formed during reduction reacted with graphite at typical FTS temperatures $(473-773 \mathrm{~K})$. The maximum sample thickness was set by the inner diameter of the quartz capillary $(0.8$ $\mathrm{mm})$. Reference compounds were also diluted with graphite to $10 \mathrm{wt} \% \mathrm{Fe}$ and held using a Prolene film against an Al plate containing a beam slit.

In Situ X-ray Absorption Microreactor Cell. An in situ $\mathrm{X}$-ray absorption reaction cell ${ }^{22}$ was designed as a modified version of a previously reported reaction cell. ${ }^{19}$ The modifications consisted of a finned heated block designed to replace the temperature control by heated air used in the earlier design. The cell consists of a quartz capillary $(0.8 \mathrm{~mm}$ inner diameter, $0.1 \mathrm{~mm}$ wall thickness, $100 \mathrm{~mm}$ length) mounted horizontally into a stainless steel base using metal fittings and graphite ferrules (Figure 1). Samples with 180-250 $\mu \mathrm{m}$ particles formed a dense bed through which gas flows with negligible pressure drop and plug-flow hydrodynamics. Heat is supplied by four cartridge heaters mounted into a finned copper block. The copper block was insulated using a ceramic foam casing. A $20 \times 4$ $\mathrm{mm}$ beam path was cut into the finned copper block and the ceramic insulation in order to provide a clear path for the X-ray beam $(10 \times 0.2 \mathrm{~mm})$ at a $45^{\circ}$ angle through the middle section of the capillary.

Gases were introduced into the cell from lecture bottles mounted in a portable gas manifold unit with built-in gas purifiers $\left(\mathrm{O}_{2}\right.$ remover; $13 \mathrm{X}$ molecular sieve; Matheson) and mass flow controllers (Porter Instruments). Features of this XAS cell include small sample loadings $(1-10 \mathrm{mg})$, low flow rates $(1.3-13.4 \mathrm{mmol} / \mathrm{h})$, and plug-flow hydrodynamics, as well as the ability to attain conversions and space velocities similar to 
those typical of laboratory tubular microreactors. The capillary microreactor can reach temperatures of $\sim 973 \mathrm{~K}$ and pressures up to $1.0 \mathrm{MPa}$. It also provides efficient heat transfer and accurate temperature control and measurement. A thermocouple ( $0.5 \mathrm{~mm}$ outer diameter) inserted into the outlet side of the capillary using a metal T-union provides accurate temperature measurements and prevents the sample from being dislodged from the capillary by the flowing gas. Temperature uniformity was confirmed by measuring the temperature profile along the sample bed under conditions identical to those used for the in situ experiments. The typical temperature variation along the sample bed is within $\pm 0.5 \mathrm{~K}$. During in situ measurements, the cell temperatures can be controlled within $\pm 0.5 \mathrm{~K}$ in either temperature-programmed or isothermal modes using a temperature controller (Series 982, Watlow). For the quench experiments described below, the capillary cell can be cooled to ambient temperature within a few seconds by simply sliding the heating block away from the capillary cell.

Measurements of X-ray Absorption Spectra. Fe K-edge X-ray absorption spectra were measured at the Stanford Synchrotron Radiation Laboratory (SSRL) on a wiggler sidestation (beamline 4-1). During these measurements, the storage ring was operated at $30-100 \mathrm{~mA}$ and $3.0 \mathrm{GeV}$. Two $\mathrm{Si}(111)$ crystals were used in the monochromator, which was detuned by $20 \%$ in order to eliminate harmonics from the monochromatic beam. Three $\mathrm{N}_{2}$-filled ion chambers were used in order to measure the intensity of the X-ray beam incident on the sample $\left(I_{0}\right)$, after the sample $\left(I_{1}\right)$, and after a $5 \mu \mathrm{m}$ Fe calibration foil $\left(I_{2}\right)$. In this manner, the sample spectrum $\left(I_{0} / I_{1}\right)$ and a reference spectrum $\left(I_{1} / I_{2}\right)$ were obtained simultaneously. The most restrictive aperture along the beam path was the $0.2 \times 12 \mathrm{~mm}$ slit within the hutch, which provided a resolution better than $2 \mathrm{eV}$ at the Fe K-edge $(7.112 \mathrm{keV}){ }^{23}$

To achieve the required time resolution for spectrum measurements during temperature-programmed reduction and carburization in $\mathrm{CO}$, a slow heating rate was used $(0.017 \mathrm{~K} / \mathrm{s})$ and only the near-edge spectra were measured (6.900-7.350 keV; $120 \mathrm{~s}$ per spectrum). After isothermal exposure to synthesis gas for $8-14 \mathrm{~h}$, the spectra were recorded in the full energy range (6.900-8.120 keV; $0.33 \mathrm{~h}$ per spectrum) in order to measure accurate spectra in both the near-edge and the fine structure regions.

X-ray Absorption Data Analysis. X-ray absorption data were analyzed using WinXAS (version 1.2$).{ }^{24}$ Raw spectra were shifted in energy in order to align the first inflection point in the Fe foil calibration spectra with the known absorption energy of Fe metal $(7.112 \mathrm{keV}) .{ }^{23}$ Linear fits to the pre-edge region $(6.900-7.100 \mathrm{keV})$ were subtracted from the spectra, and the spectra were normalized by a sixth-order polynomial fit of the post-edge region $(7.240-8.120 \mathrm{keV})$. Principal component analysis $^{16}$ and linear combination methods ${ }^{17}$ were used to calculate the relative abundance of the various Fe phases using the near-edge spectral region between 7.090 and $7.240 \mathrm{keV}$ for each sample and for the Fe reference compounds.

The approach used to identify chemical species and to measure their relative abundance involves using linear combinations of the spectra from reference compounds, which include the structures thought to be present in the sample, to fit the experimental near-edge spectra of each sample. In the present case, it is difficult to anticipate which of the many possible $\mathrm{Fe}$ carbides, oxides, and oxycarbides may be formed during reactions with $\mathrm{CO}$ or with synthesis gas. Moreover, some species may be stable only under FT synthesis conditions. Thus, they are not necessarily available as structurally pure references. In view of this, we have used principal component analysis (PCA) in order to identify sets of spectral features that increase or diminish in synchrony as the spectral series progresses. These sets of features comprise contributions from the spectra of chemical species that change in concentration as the sample evolves under in situ treatments.

During the reduction and carburization of $\mathrm{Fe}$ oxides in $\mathrm{CO}$ or in synthesis gas, PCA identified three major components involved in the phase changes; these components were $\mathrm{Fe}_{2} \mathrm{O}_{3}$, $\mathrm{Fe}_{3} \mathrm{O}_{4}$, and a carbide resembling $\mathrm{Fe}_{3} \mathrm{C}$. Therefore, in situ spectra were described using a linear combination of the near-edge spectra of these three reference compounds. $\mathrm{Fe}$ and $\mathrm{FeO}$ were specifically rejected by the PCA analysis, and their presence in linear combinations did not improve the spectral fits, suggesting that $\mathrm{Fe}$ and $\mathrm{FeO}$ do not occur as intermediate phases during reduction and carburization of $\mathrm{Fe}_{2} \mathrm{O}_{3}$ precursors. The target transform application of the PCA led to an excellent fit quality to $\mathrm{Fe}_{3} \mathrm{C}$, using components generated from our catalyst spectra. The analysis of the fine structure, however, indicated that the carburized Fe catalyst did not achieve sufficient long-range order to be rigorously described as a specific crystallographic phase of $\mathrm{Fe}$ carbide; therefore, we refer to it only as $\mathrm{FeC}_{x}$ throughout the rest of this report.

Fischer-Tropsch Synthesis Reaction Rate Measurements. Isothermal transient experiments to measure rates of product formation at conditions, similar to those for in situ XAS measurements, were carried out using on-line mass spectrometric analysis. A $0.2 \mathrm{~g}$ sample diluted with graphite $(0.5 \mathrm{~g}, 180-250$ $\mu \mathrm{m}$, Alfa AESAR, 99.998\%) was loaded into a quartz microreactor and treated in $\mathrm{He}$ (Matheson, $99.999 \%, 0.268 \mathrm{~mol} / \mathrm{h}$ ) at temperatures up to $573 \mathrm{~K}$ and cooled in $\mathrm{He}$ to $523 \mathrm{~K}$. The He stream was switched to a flow of synthesis gas in $\mathrm{Ar}\left(\mathrm{H}_{2} / \mathrm{CO} /\right.$ $\mathrm{Ar}=40 / 20 / 40 \mathrm{kPa}$, Matheson, $99.999 \%$, total molar rate 0.268 $\mathrm{mol} / \mathrm{h}$ ) at $523 \mathrm{~K}$. The resulting isothermal transients in the rate of evolution of several FTS products $\left(\mathrm{CH}_{4}, \mathrm{H}_{2} \mathrm{O}\right.$ and $\mathrm{CO}_{2}$, etc. $)$ were measured as a function of time using on-line mass spectrometry (Leybold Inficon, Transpector Series). The rate of formation of $\mathrm{CH}_{4}$ was used as a surrogate measure of the total FTS rates, because it can be measured accurately and changes with time on stream in parallel with the rate of formation of other hydrocarbon products. $\mathrm{CH}_{4}$ selectivities change with time on stream by less than $5 \%$; therefore, $\mathrm{CH}_{4}$ formation rates accurately reflect the total rate of hydrocarbon synthesis.

CO Chemisorption and Surface Area Measurements. Precipitated $\mathrm{Fe}$ oxides ( $0.2 \mathrm{~g}$; diluted with graphite) were treated in flowing $\mathrm{He}(0.268 \mathrm{~mol} / \mathrm{h})$ up to $573 \mathrm{~K}$ and then cooled to $523 \mathrm{~K}$. The He stream was switched to a $\mathrm{H}_{2} / \mathrm{CO} / \mathrm{Ar}$ stream (40/ $20 / 40 \mathrm{kPa} ; 0.268 \mathrm{~mol} / \mathrm{h}$ ) at $523 \mathrm{~K}$ for $1 \mathrm{~h}$ and flushed with $\mathrm{He}$ $(0.268 \mathrm{~mol} / \mathrm{h})$ at this temperature for $1 \mathrm{~h}$ in order to remove any reversibly adsorbed species. The samples were then cooled to RT before $\mathrm{CO}$ chemisorption and BET surface area measurements.

Two sets of temperature-programmed desorption (TPD) experiments were performed. In one experiment, a flow of $\mathrm{CO} /$ Ar stream $(20 / 80 \mathrm{kPa} ; 0.268 \mathrm{~mol} / \mathrm{h})$ was passed through the sample for $0.5 \mathrm{~h}$. Physisorbed species were removed by flushing the sample using $\operatorname{Ar}(0.268 \mathrm{~mol} / \mathrm{h})$ for $0.5 \mathrm{~h}$. The amount of carbon species $\mathrm{CO}_{x}\left(\mathrm{CO}+\mathrm{CO}_{2}\right)$ evolved as the samples were heated in Ar flow $(0.268 \mathrm{~mol} / \mathrm{h})$ at $0.167 \mathrm{~K} / \mathrm{s}$ to $1000 \mathrm{~K}$ was measured by mass spectrometry. Another set of experiments followed the same protocol but without a $\mathrm{CO}$ chemisorption after FTS reaction. The difference between the peak areas under these two TPD curves was taken as a measure of the availability 


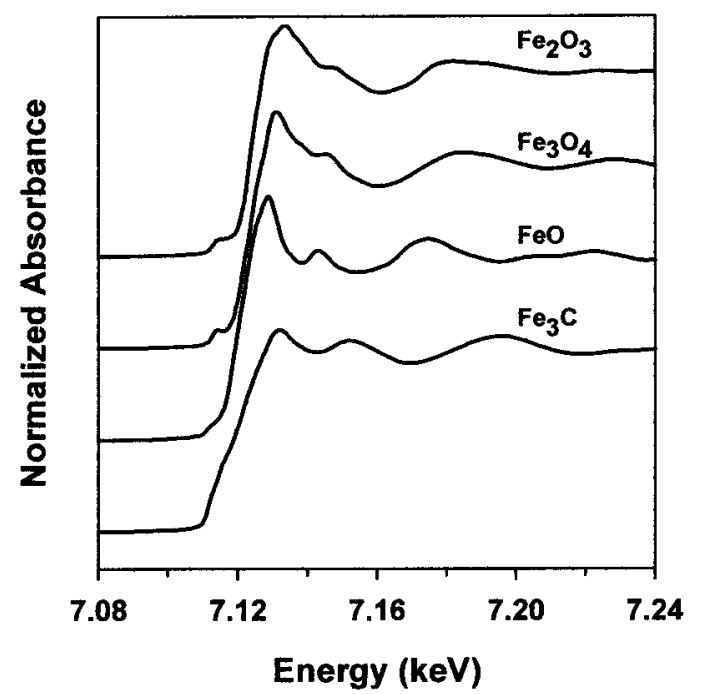

Figure 2. Normalized $\mathrm{Fe} \mathrm{K}$-edge X-ray absorption spectra for $\mathrm{Fe}$ oxides and carbide.

TABLE 1: Absorption Edge Energies for Fe Compounds with Known Structure and Oxidation State

\begin{tabular}{llllll}
\hline compound & $\mathrm{Fe}$ & $\mathrm{Fe}_{3} \mathrm{C}$ & $\mathrm{FeO}$ & $\mathrm{Fe}_{3} \mathrm{O}_{4}$ & $\mathrm{Fe}_{2} \mathrm{O}_{3}$ \\
binding energy (keV) & 7.112 & 7.112 & 7.119 & 7.123 & 7.124
\end{tabular}

of active sites capable of chemisorbing $\mathrm{CO}$ reversibly at FTS temperatures. This method allows us to subtract from the total $\mathrm{CO}$ evolved those $\mathrm{CO}$ species formed from irreversibly adsorbed carbon species during FTS, as well as the $\mathrm{CO}_{x}$ produced from reaction of $\mathrm{FeC}_{x}$ with residual $\mathrm{Fe}$ oxides at temperatures much higher than those of the FTS reaction.

BET surface area measurements were carried out on samples after FTS reaction at $523 \mathrm{~K}$ and quenching to RT by passivating catalyst samples in flowing $1 \% \mathrm{O}_{2} / \mathrm{He}$ at RT. $\mathrm{N}_{2}$ physisorption measurements were performed at its normal boiling point (77 K) using an Autosorb 6 system (Quantachrome, Inc.). Surface areas were calculated using the BET method.

\section{Results and Discussion}

1. Fe K-Edge XANES of Reference Compounds. Figure 2 shows the near-edge spectra for the $\mathrm{Fe}_{3} \mathrm{C}, \mathrm{FeO}, \mathrm{Fe}_{3} \mathrm{O}_{4}$, and $\mathrm{Fe}_{2} \mathrm{O}_{3}$ reference compounds. The absorption edge at $\sim 7.120 \mathrm{keV}$ is caused by the ejection of Fe 1 s electrons after absorption of a photon. The measured absorption edge energies for all reference compounds are listed in Table 1 . These binding energies of $1 \mathrm{~s}$ electrons increase with increasing $\mathrm{Fe}$ valence. The weak preedge features in the spectra of $\mathrm{Fe}$ oxides reflect electronic transitions from $1 \mathrm{~s}$ atomic orbitals to unoccupied $\mathrm{p}-\mathrm{d}$ hybrid molecular orbital final states; these transitions are dipoleforbidden in noncentrosymmetric structures.

2. In Situ Fe K-Edge XANES during Reactions of Fe Oxide Precursors with CO. Figure 3 shows $\mathrm{Fe}$ near-edge spectra for the $\mathrm{Fe}_{2} \mathrm{O}_{3}$ sample during exposure to $\mathrm{CO}$. No detectable changes in the spectra occurred below $450 \mathrm{~K}$. Gradual changes occurred at temperatures between 450 and $600 \mathrm{~K}$, but the spectra then remained unchanged at higher temperatures. Thus, it appears that the formation of a stable compound is complete by $\sim 600 \mathrm{~K}$. A qualitative comparison of the reference spectra (Figure 2) with those of the samples after exposure to $\mathrm{CO}$ (Figure 3 ) suggests that structural transformations involve the intermediate formation of $\mathrm{Fe}_{3} \mathrm{O}_{4}$ and its ultimate conversion to $\mathrm{FeC}_{x}$.

A more quantitative assessment of these transformations is shown in Figure 4, which shows the relative abundances of the

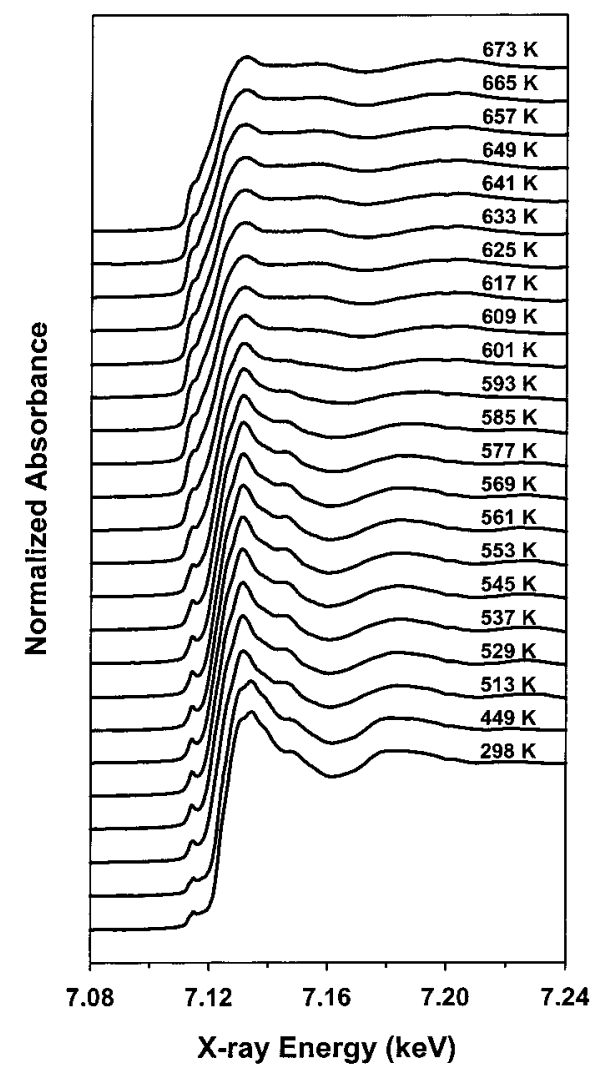

Figure 3. In situ $\mathrm{Fe} \mathrm{K}$-edge $\mathrm{XANES}$ spectra for $\mathrm{Fe}$ oxide in $\mathrm{CO}$ as a function of temperature $\left(1 \mathrm{mg}\right.$ of precipitated $\mathrm{Fe}_{2} \mathrm{O}_{3}$, $\mathrm{CO}$ flow rate $=$ $107 \mathrm{~mol} / \mathrm{g}$-atom Fe-h).

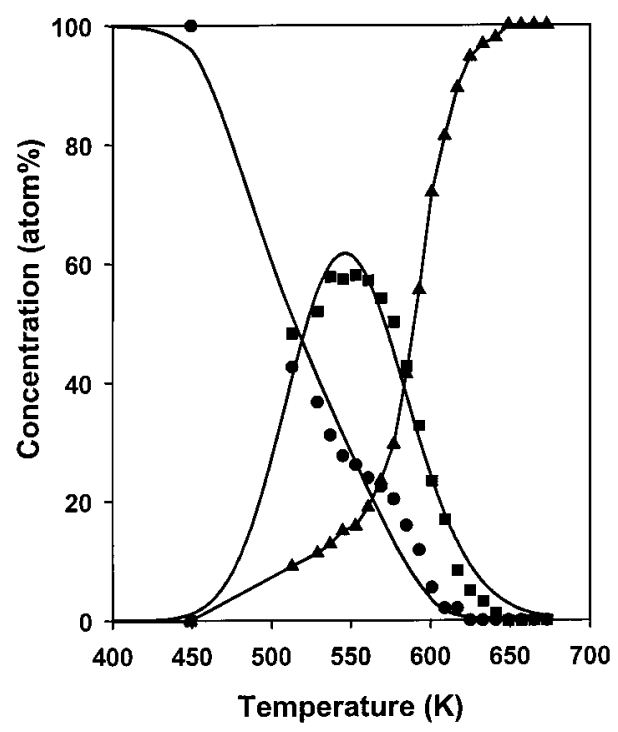

Figure 4. In situ evolution of $\mathrm{Fe}_{2} \mathrm{O}_{3}$ in $\mathrm{CO}$ as a function of temperature ( $1 \mathrm{mg}$ of precipitated $\mathrm{Fe}_{2} \mathrm{O}_{3}$, CO flow rate $=107 \mathrm{~mol} / \mathrm{g}$-atom $\mathrm{Fe}-\mathrm{h}$ ): $\mathrm{Fe}_{2} \mathrm{O}_{3}$ (circle); $\mathrm{Fe}_{3} \mathrm{O}_{4}$ (square); $\mathrm{FeC}_{x}$ (triangle).

various phases required to describe the experimental near-edge spectra during reduction and carburization of $\mathrm{Fe}_{2} \mathrm{O}_{3}$ in $\mathrm{CO}$. The reduction of $\mathrm{Fe}_{2} \mathrm{O}_{3}$ did not start until $\sim 450 \mathrm{~K}$. Above $450 \mathrm{~K}$, the relative abundance of $\mathrm{Fe}_{3} \mathrm{O}_{4}$ increased, and then it decreased above $550 \mathrm{~K}$, as $\mathrm{Fe}_{3} \mathrm{O}_{4}$ was converted to $\mathrm{FeC}_{x}$. The concentration profiles for $\mathrm{Fe}_{2} \mathrm{O}_{3}, \mathrm{Fe}_{3} \mathrm{O}_{4}$, and $\mathrm{FeC}_{x}$ suggest that these transformations occurred in a sequential manner. The evidence of rapid conversion of $\mathrm{Fe}_{3} \mathrm{O}_{4}$ to $\mathrm{FeC}_{x}$ (Figure 4) was provided by detailed temperature-programmed reduction and carburization studies of $\mathrm{Fe}_{2} \mathrm{O}_{3}$ in $\mathrm{CO}^{25}$ with concurrent measurements of the amounts of $\mathrm{CO}_{2}$ evolved and of $\mathrm{CO}$ consumed. The reduction 


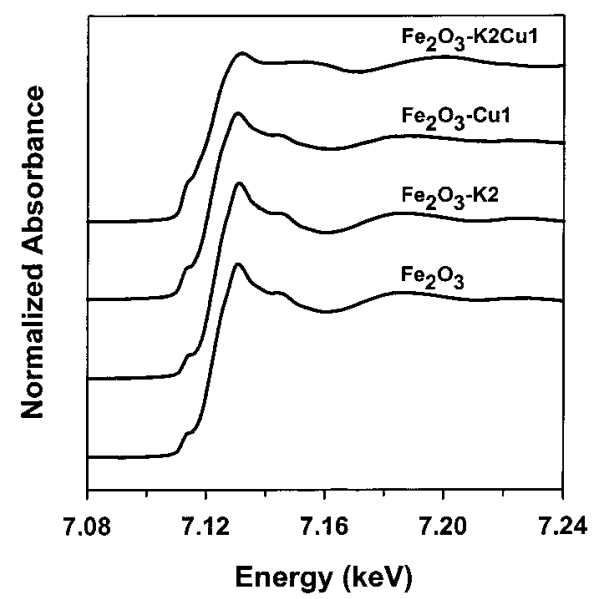

Figure 5. In situ $\mathrm{Fe} \mathrm{K}$-edge spectra of $\mathrm{Fe}-\mathrm{K}-\mathrm{Cu}$ oxides in synthesis gas at $523 \mathrm{~K}$ for $5 \mathrm{~h}\left(1 \mathrm{mg}\right.$ of precipitated $\mathrm{Fe}_{2} \mathrm{O}_{3}, \mathrm{H}_{2} / \mathrm{CO}=2$, synthesis gas flow rate $=107 \mathrm{~mol} / \mathrm{g}$-atom Fe-h).

and carburization of $\mathrm{Fe}_{2} \mathrm{O}_{3}$ in synthesis gas $\left(\mathrm{H}_{2} / \mathrm{CO}=2\right)$ followed the same reaction sequence as in $\mathrm{CO}$, except that all structural changes occurred at slightly higher temperatures $(\Delta T$ $\sim 20 \mathrm{~K})$.

3. In Situ X-ray Absorption Spectra of $\mathrm{Fe}-\mathrm{K}-\mathrm{Cu}$ Oxide Precursors in Synthesis Gas. 3.1. In Situ Fe K-Edge XANES. Previous studies have shown that both $\mathrm{K}$ and $\mathrm{Cu}$ markedly increase FTS and water-gas shift reaction rates. ${ }^{1,2}$ Potassium also increases the olefin content and the molecular weight of FTS products. ${ }^{26}$ The evolution of the Fe near-edge spectral features in $\mathrm{Fe}$ and $\mathrm{Fe}-\mathrm{K}-\mathrm{Cu}$ oxide precursors during exposure to synthesis gas was used in order to examine the effects of $\mathrm{H}_{2}$ in modifying the structural details detected during carburization in $\mathrm{CO}$, as well as the role of the $\mathrm{K}$ and $\mathrm{Cu}$ on the rate and products of the transformation that occurs during the initial exposure of these oxide precursors to synthesis gas.

Figure 5 shows the near-edge spectra for $\mathrm{Fe}, \mathrm{Fe}-\mathrm{Cu}, \mathrm{Fe}-\mathrm{K}$, and $\mathrm{Fe}-\mathrm{K}-\mathrm{Cu}$ oxide precursors measured in situ after contact with synthesis gas at $523 \mathrm{~K}$ for $5 \mathrm{~h}$. The absorption edge energy was lower and the spectra resembled the Fe carbide spectrum (Figure 2) more closely when $\mathrm{K}$ or $\mathrm{Cu}$ was present in the sample. These effects of $\mathrm{Cu}$ or $\mathrm{K}$ were even stronger when both promoters were present.

3.2. Effects of $K$ and $C u$ on Catalyst Structure and on Fischer-Tropsch Synthesis Rates. The spectra of $\mathrm{Fe}, \mathrm{Fe}-\mathrm{Cu}$, $\mathrm{Fe}-\mathrm{K}$, and $\mathrm{Fe}-\mathrm{K}-\mathrm{Cu}$ oxide precursors during exposure to synthesis gas at $523 \mathrm{~K}$ were described by linear combinations of the near-edge spectra of reference compounds. The structural evolution of unpromoted $\mathrm{Fe}_{2} \mathrm{O}_{3}$ as a function of time is shown in Figure 6. The $\mathrm{Fe}_{3} \mathrm{O}_{4}$ and $\mathrm{FeC}_{x}$ contributions approached constant values of $\sim 70 \%$ and $\sim 30 \%$, respectively, after $\sim 4 \mathrm{~h}$. Carburization rates then decreased as the remaining Fe oxides became covered by a dense Fe carbide coating, which appears to inhibit the rate-determining oxygen diffusion step required for carburization processes. At $543 \mathrm{~K}$, the $\mathrm{FeC}_{x}$ contribution increased to $\sim 45 \%$ after $4 \mathrm{~h}$, apparently because of faster oxygen diffusion at higher temperatures. Previous studies have suggested that the reduction and carburization (or nitridation) of transitionmetal oxides are limited by the bulk diffusion of oxygen in the lattice of the corresponding oxide. This was inferred from the excellent agreement between the activation energies for the synthesis of transition-metal carbides or nitrides and those for the diffusion of oxygen in the oxides. ${ }^{27,28}$ The absence of Fe metal or $\mathrm{FeO}$ in the near-edge spectra of these samples confirms the rate-determining nature of oxygen diffusion steps. If the

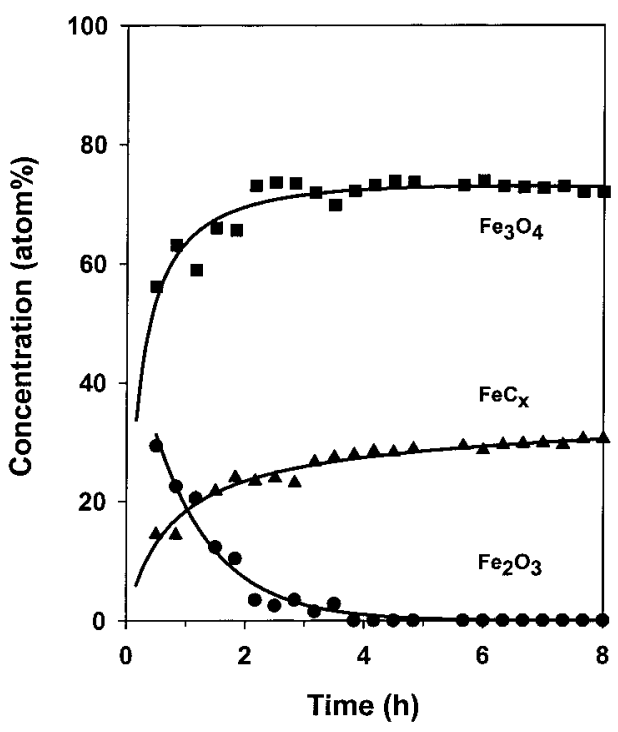

Figure 6. Phase evolution of $\mathrm{Fe}_{2} \mathrm{O}_{3}$ with time on stream after exposure to synthesis gas at $523 \mathrm{~K}\left(1 \mathrm{mg}\right.$ of precipitated $\mathrm{Fe}_{2} \mathrm{O}_{3}, \mathrm{H}_{2} / \mathrm{CO}=2$, synthesis gas flow rate $=107 \mathrm{~mol} / \mathrm{g}$-atom Fe-h).

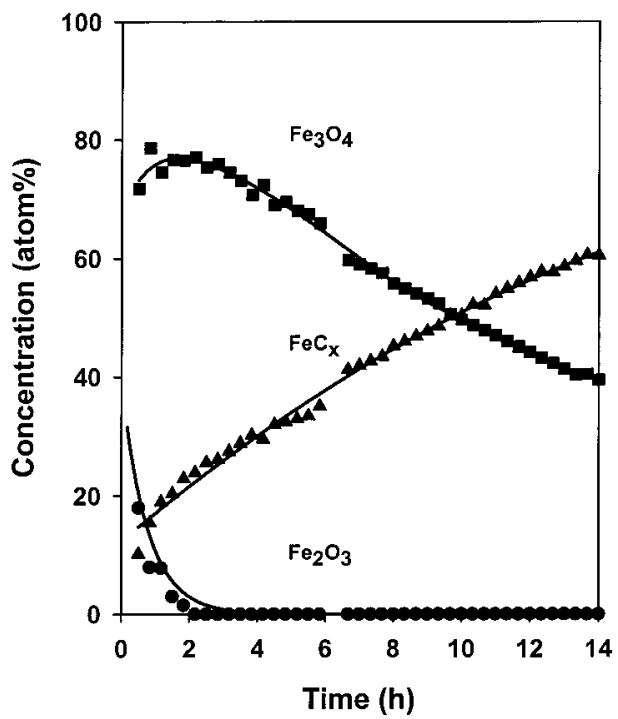

Figure 7. Phase evolution of $\mathrm{Fe}-\mathrm{Cu}$ oxide with time on stream after exposure to synthesis gas at $523 \mathrm{~K}\left(1 \mathrm{mg}\right.$ of precipitated $\mathrm{Fe}_{2} \mathrm{O}_{3}, \mathrm{Cu} / \mathrm{Fe}$ $=0.01, \mathrm{H}_{2} / \mathrm{CO}=2$, synthesis gas flow rate $=107 \mathrm{~mol} / \mathrm{g}$-atom Fe-h).

removal of oxygen atoms at crystallite surfaces or at oxidecarbide interfaces had occurred without the immediate availability of carbon to react with the resulting reduced species, nucleation of Fe metal and $\mathrm{FeO}$ crystallites would have occurred and such phases would have been detected by X-ray absorption.

Figure 7 shows the structural evolution of $\mathrm{Fe}-\mathrm{Cu}$ oxide precursors $(\mathrm{Cu} / \mathrm{Fe}=0.01)$ during exposure to synthesis gas $\left(\mathrm{H}_{2} /\right.$ $\mathrm{CO}=2$ ) at $523 \mathrm{~K}$ for $14 \mathrm{~h}$. These data show that $\mathrm{Fe}_{2} \mathrm{O}_{3}$ converts to $\mathrm{Fe}_{3} \mathrm{O}_{4}$, and subsequently to $\mathrm{FeC}_{x}$ more rapidly than for the unpromoted $\mathrm{Fe}$ oxide samples (Figure 6). $\mathrm{CuO}$ reduces to $\mathrm{Cu}$ readily in $\mathrm{H}_{2}$ at $523 \mathrm{~K}$; once reduced, it provides sites for $\mathrm{H}_{2}$ dissociation, which leads to adsorbed hydrogen species that reduce $\mathrm{Fe}_{2} \mathrm{O}_{3}$ to $\mathrm{Fe}_{3} \mathrm{O}_{4}$ at lower temperatures than for unpromoted $\mathrm{Fe}_{2} \mathrm{O}_{3}$.

The ultimate extent of carburization after long contact times (8 h) was also higher for $\mathrm{Fe}-\mathrm{Cu}$ oxides $(\sim 45 \%$; Figure 7$)$ than for unpromoted Fe oxide samples ( $\sim 30 \%$; Figure 6$)$. The more complete carburization of $\mathrm{Cu}$-containing $\mathrm{Fe}_{2} \mathrm{O}_{3}$ precursors would be unexpected without changes in the size of the crystalline 
structures, because carburization rates become ultimately controlled by the rate of oxygen diffusion. Oxygen diffusion rates cannot be influenced by the mere presence of $\mathrm{Cu}$ metal sites at the surface of such structures. Instead, it appears that the presence of $\mathrm{Cu}$ metal species at $\mathrm{Fe}_{2} \mathrm{O}_{3}$ surfaces leads to the simultaneous formation of a larger number of $\mathrm{Fe}_{3} \mathrm{O}_{4}$ or $\mathrm{FeC}_{x}$ nuclei, which then grow to consume a large fraction of the remaining $\mathrm{Fe}_{2} \mathrm{O}_{3}$ starting material. In contrast, the nucleation of these phases on unpromoted $\mathrm{Fe}_{2} \mathrm{O}_{3}$ surfaces is likely to proceed through the formation of a more uniform shrinking core of $\mathrm{FeO}_{x}$ encapsulated by a growing $\mathrm{FeC}_{x}$ layer or at least via the initial formation of a smaller number of nuclei. Our parallel XAS studies of the structural evolution of $\mathrm{Fe}_{2} \mathrm{O}_{3}$ during initial exposure to synthesis gas ${ }^{25}$ have shown that $\mathrm{Fe}_{2} \mathrm{O}_{3}$, once reduced to $\mathrm{Fe}_{3} \mathrm{O}_{4}$, readily reduces and carburizes to $\mathrm{FeC}_{x}$, at least in near-surface regions, as indicated by the concurrent formation of $\mathrm{Fe}_{3} \mathrm{O}_{4}$ and $\mathrm{FeC}_{x}$ and by the rapid attainment of steady-state FTS reaction rates.

The conversion of $\mathrm{Fe}_{3} \mathrm{O}_{4}$ to $\mathrm{Fe}_{3} \mathrm{C}$ is accompanied by a substantial decrease in crystallite volume, because of the lower density of $\mathrm{Fe}_{3} \mathrm{O}_{4}\left(5.2 \mathrm{~g} / \mathrm{cm}^{3}\right)$ compared with $\mathrm{FeC}_{x}\left(7.7 \mathrm{~g} / \mathrm{cm}^{3}\right.$ for $\left.\mathrm{Fe}_{3} \mathrm{C}\right){ }^{29}$ The dense $\mathrm{Fe}$ carbide layers formed at pure $\mathrm{Fe}_{3} \mathrm{O}_{4}$ surfaces apparently provide an effective barrier to the diffusion of oxygen. In addition, the carburization of the shrinking oxide core cannot continue to completion without the nucleation of a void or the shattering of the carbide shell because of the density mismatch between the two phases. This shrinking core type of reduction is similar to the model proposed in previous studies of the reduction behavior of transition-metal oxides. ${ }^{30}$

The simultaneous formation of a larger number of $\mathrm{FeC}_{x}$ nuclei on $\mathrm{Cu}$-promoted $\mathrm{Fe}_{2} \mathrm{O}_{3}$ leads to the growth of smaller carbide regions, which avoid both the longer diffusion paths and the void nucleation or shell breakup required in pure $\mathrm{Fe}_{3} \mathrm{O}_{4}$. This leads, in turn, to more complete carburization and to smaller $\mathrm{FeC}_{x}$ structures, with a higher surface area and a smaller oxygen diffusion distance, and with a larger density of sites for $\mathrm{CO}$ activation. The apparent correlation between FTS rates and the extent of carburization is not causal. Instead, both reflect the smaller size of the active carbide structures that form during FTS when $\mathrm{Cu}$ is present on the $\mathrm{Fe}_{2} \mathrm{O}_{3}$ precursors. This finding resolves the puzzling observed correlation between the extent of carburization and FTS rates, even when the formation of only a few near-surface layers of $\mathrm{FeC}_{x}$ is apparently sufficient to achieve steady-state FTS reaction rates. Although only the incipient conversion of $\mathrm{Fe}_{3} \mathrm{O}_{4}$ to $\mathrm{FeC}_{x}$ is required for $\mathrm{Fe}_{2} \mathrm{O}_{3}$ or $\mathrm{Cu}$-containing $\mathrm{Fe}_{2} \mathrm{O}_{3}$ precursors to become active in FTS reactions, the smaller and more extensively carburized structures formed when $\mathrm{Cu}$ is present lead to the higher FTS rates observed on $\mathrm{Cu}$-containing $\mathrm{Fe}_{2} \mathrm{O}_{3}$ precursors. ${ }^{25}$ As we describe immediately below, $\mathrm{K}$ has a similar effect as $\mathrm{Cu}$ on FTS rates and on the rate and extent of carburization of $\mathrm{Fe}_{2} \mathrm{O}_{3}$ precursors.

$\mathrm{Fe}_{2} \mathrm{O}_{3}$ precursors modified by $\mathrm{K}(\mathrm{K} / \mathrm{Fe}=0.02)$ reduce and carburize even more rapidly than $\mathrm{Cu}$-promoted $\mathrm{Fe}_{2} \mathrm{O}_{3}$ (Figure 8 ), consistent with our reduction and carburization kinetic measurements on these samples in both $\mathrm{CO}$ and $\mathrm{H}_{2} / \mathrm{CO}$ reactants. The similar reduction-carburization promotion introduced by $\mathrm{K}$ in both $\mathrm{CO}$ and $\mathrm{H}_{2} / \mathrm{CO}$ suggests that the role of $\mathrm{K}$ is to increase the rate of $\mathrm{CO}$ activation on $\mathrm{Fe}_{2} \mathrm{O}_{3}$ surfaces. ${ }^{25}$ In contrast, the effect of $\mathrm{Cu}$ is most evident when $\mathrm{H}_{2}$ is also present with $\mathrm{CO}$, because of the role of $\mathrm{Cu}$ surfaces as $\mathrm{H}_{2}$ dissociation sites. The presence of dispersed $\mathrm{K}$ species, probably as carbonates, also leads to the rapid incipient formation of multiple $\mathrm{Fe}_{3} \mathrm{O}_{4}$ and $\mathrm{FeC}_{x}$ nuclei and to the ultimate formation of smaller crystallites with carbided surfaces. In this manner,

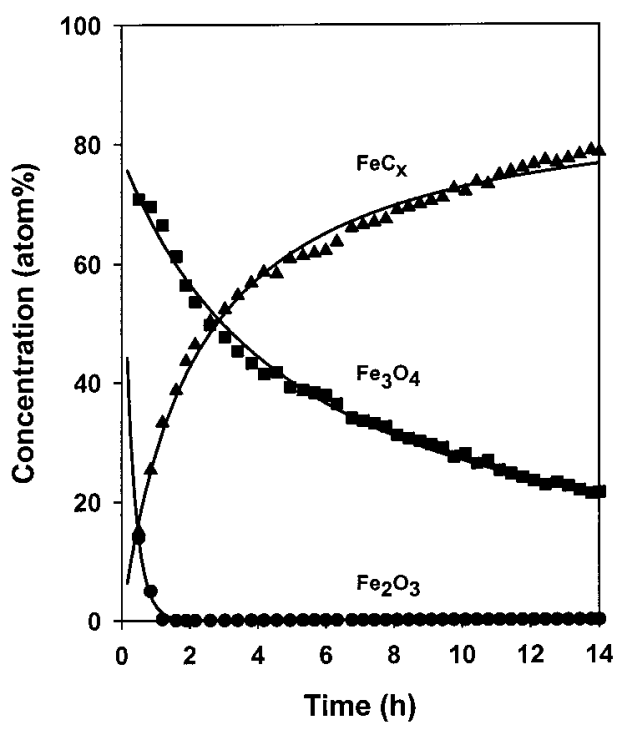

Figure 8. Phase evolution of $\mathrm{Fe}-\mathrm{K}$ oxide with time on stream after exposure to synthesis gas at $523 \mathrm{~K}\left(1 \mathrm{mg}\right.$ of precipitated $\mathrm{Fe}_{2} \mathrm{O}_{3}, \mathrm{~K} / \mathrm{Fe}$ $=0.02, \mathrm{H}_{2} / \mathrm{CO}=2$, synthesis gas flow rate $=107 \mathrm{~mol} / \mathrm{g}$-atom Fe-h).

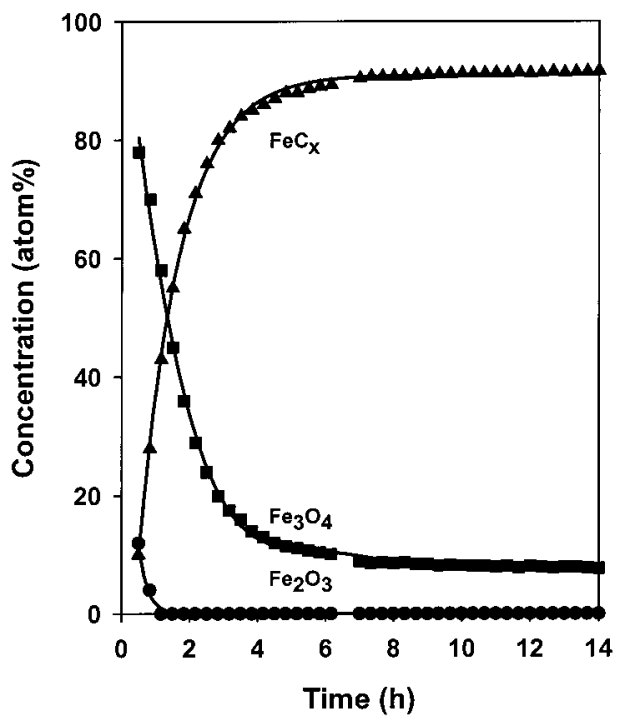

Figure 9. Phase evolution of $\mathrm{Fe}-\mathrm{K}-\mathrm{Cu}$ oxide with time on stream after exposure to synthesis gas at $523 \mathrm{~K}\left(1 \mathrm{mg}\right.$ of precipitated $\mathrm{Fe}_{2} \mathrm{O}_{3}$, $\mathrm{K} / \mathrm{Fe}=0.02, \mathrm{Cu} / \mathrm{Fe}=0.01, \mathrm{H}_{2} / \mathrm{CO}=2$, synthesis gas flow rate $=$ $107 \mathrm{~mol} / \mathrm{g}$-atom $\mathrm{Fe}-\mathrm{h})$.

we reconcile the similar directional effects of $\mathrm{Cu}$ and $\mathrm{K}$ on FTS reaction rates and the apparent inconsistency between the positive effects of the higher extents of carburization induced by $\mathrm{K}$ and $\mathrm{Cu}$ and the rate increase for FTS reactions, which appear to require only the near-surface conversion of Fe oxides to $\mathrm{FeC}_{x}{ }^{25}$ During the incipient conversion of $\mathrm{Fe}$ oxides to carbides upon contact with synthesis gas, $\mathrm{CH}_{4}$ formation rates initially increased rapidly as a layer of $\mathrm{FeC}_{x}$ formed, and then they increased at a slower rate as the surface area of the $\mathrm{FeC}_{x}$ structures continued to increase gradually with increasing extent of carburization. ${ }^{25}$ Ultimately both the $\mathrm{FeC}_{x}$ content and the FTS rates reached their corresponding steady-state values.

Reduction and carburization processes were even faster when both $\mathrm{Cu}$ and $\mathrm{K}$ were present (Figure 9) than when samples were promoted by either $\mathrm{K}$ or $\mathrm{Cu}$ (Figures 7 and 8). Apparently, the presence of a larger number of activation sites provided by the combined contributions of both $\mathrm{Cu}$ and $\mathrm{K}$ at $\mathrm{Fe}_{2} \mathrm{O}_{3}$ surfaces, leads to an even larger number of incipient nuclei points than when only one of these promoters is present. The resulting 
TABLE 2: Surface Area and CO Chemisorption Results after 1 h FTS Reactions; (Fe Carbide Concentrations Obtained from in Situ XAS and $\mathrm{CH}_{4}$ Formation Rates from Transient Experiments, after $5 \mathrm{~h}$ FTS Reactions)

\begin{tabular}{|c|c|c|c|c|}
\hline oxide precursor & $\mathrm{Fe}$ & $\mathrm{Fe}-\mathrm{Cu}$ & $\mathrm{Fe}-\mathrm{K}$ & $\mathrm{Fe}-\mathrm{K}-\mathrm{Cu}$ \\
\hline surface area $\left(\mathrm{m}^{2} / \mathrm{g}\right)$ & 13 & 17 & 18 & 23 \\
\hline amt of $\mathrm{CO}_{x}$ desorbed before $\mathrm{CO}$ chemisorption $(\mathrm{mmol} / \mathrm{g}$-atom $\mathrm{Fe}$ ) & 12.2 & 14.1 & 23.4 & 56.9 \\
\hline amt of $\mathrm{CO}_{x}$ desorbed after $\mathrm{CO}$ chemisorption $(\mathrm{mmol} / \mathrm{g}$-atom $\mathrm{Fe})$ & 20.3 & 27.9 & 40.9 & 95.7 \\
\hline amt of $\mathrm{CO}$ chemisorbed ( $\mathrm{mmol} / \mathrm{g}$-atom $\mathrm{Fe})$ & 8.1 & 13.8 & 17.5 & 38.8 \\
\hline CO chemisorption site density (molecule/nm²) & 5 & 6 & 7 & 13 \\
\hline $\mathrm{FeC}_{x}$ concentration $^{a}($ atom $\%)$ & 28.8 & 32.4 & 60.8 & 88.0 \\
\hline $\mathrm{CH}_{4}$ formation rate $^{b}(\mathrm{mmol} / \mathrm{g}$-atom $\mathrm{Fe}-\mathrm{s})$ & 0.061 & 0.070 & 0.11 & 0.19 \\
\hline
\end{tabular}

${ }^{a} \mathrm{FeC}_{x}$ concentration measured after exposure to synthesis gas at $523 \mathrm{~K}$ for $5 \mathrm{~h}\left(1 \mathrm{mg}\right.$ precipitated $\mathrm{Fe}_{2} \mathrm{O}_{3}, \mathrm{~K} / \mathrm{Fe}=0.02, \mathrm{Cu} / \mathrm{Fe}=0.01, \mathrm{H}_{2} / \mathrm{CO}$ $=2$, synthesis gas flow rate $=107 \mathrm{~mol} / \mathrm{g}$-atom Fe-h). ${ }^{b} \mathrm{CH}_{4}$ formation rates measured after exposure to synthesis gas at $523 \mathrm{~K}$ for $5 \mathrm{~h}(0.2 \mathrm{~g}$ precipitated $\mathrm{Fe}_{2} \mathrm{O}_{3}, \mathrm{~K} / \mathrm{Fe}=0.02, \mathrm{Cu} / \mathrm{Fe}=0.01, \mathrm{H}_{2} / \mathrm{CO}=2$, synthesis gas flow rate $=64.3 \mathrm{~mol} / \mathrm{g}$-atom $\mathrm{Fe}-\mathrm{h}$ ).

higher density of $\mathrm{FeC}_{x}$ nuclei ultimately grow into even smaller crystallites, which provide a larger number of sites for $\mathrm{CO}$ and $\mathrm{H}_{2}$ activation, leading to even faster reduction and carburization, shorter diffusion distances required for complete carburization, and higher FTS reaction rates than on singly promoted samples.

The formation of smaller crystallites and of a higher density of active sites when $\mathrm{K}$ and/or $\mathrm{Cu}$ are present during activation is consistent with measurements of the BET surface area and the $\mathrm{CO}$ chemisorption capacity after FTS reactions for $1 \mathrm{~h}\left(\mathrm{H}_{2} /\right.$ $\mathrm{CO}=2,523 \mathrm{~K}$; Table 2). BET surface areas were higher on samples containing $\mathrm{K}$ and/or $\mathrm{Cu}$, consistent with the formation of active catalysts containing smaller crystallites. $\mathrm{CO}$ chemisorption uptakes increased with increasing BET surface area. The site density available for $\mathrm{CO}$ chemisorption was higher on $\mathrm{K}$ - or $\mathrm{Cu}$-containing samples. Chemisorption uptakes reached their highest value for samples prepared from the $\mathrm{Fe}-\mathrm{K}-\mathrm{Cu}$ oxide precursors. These values correspond to about one monolayer $\left(\sim 15 \mathrm{CO} / \mathrm{nm}^{2}\right)$ of chemisorbed $\mathrm{CO}$. This suggests that $\mathrm{K}$ and/or $\mathrm{Cu}$ promote the formation of smaller $\mathrm{Fe}$ carbide crystallites, which in turn increase the site density for $\mathrm{CO}$ adsorption/dissociation and consequently for the initial reduction and carburization and for steady-state FTS turnovers.

To explore the relation between the structure of the working catalysts and their catalytic performance, FTS rates were measured during exposure to synthesis gas at the same conditions $\left(\mathrm{H}_{2} / \mathrm{CO}=2,523 \mathrm{~K}\right)$ as the XAS experiments. Figure 10 shows the Fe carbide concentrations obtained from in situ XAS and the $\mathrm{CH}_{4}$ formation rates measured in the corresponding transient FTS experiments on unpromoted $\mathrm{Fe}_{2} \mathrm{O}_{3}$ as a function of time. The rate of formation of $\mathrm{CH}_{4}$ increased with increasing $\mathrm{FeC}_{x}$ content. This indicates that $\mathrm{Fe}$ carbide $\left(\mathrm{FeC}_{x}\right)$ is the stable Fe phase during FTS and provides the active surfaces required for FTS turnovers. On samples containing $\mathrm{K}$ and/or $\mathrm{Cu}$ (Table 2), FTS rates increased proportionally with the observed increase in $\mathrm{FeC}_{x}$ content (at long contact times) and in $\mathrm{CO}$ chemisorption uptakes. This supports the conclusion that the effect of $\mathrm{K}$ and $\mathrm{Cu}$ on the structure of catalysts is to provide a larger number of active $\mathrm{Fe}$ carbide sites for FTS reactions. The chemical promotion effects by $\mathrm{K}$ and/or $\mathrm{Cu}$ do not appear to be necessary in order to account for the increase in reaction rates observed when $\mathrm{Fe}_{2} \mathrm{O}_{3}$ precursors are impregnated with these components. $\mathrm{Cu}$ does not influence the selectivity; the effects of K on FTS selectivity will be discussed in a subsequent paper. ${ }^{21}$

Clearly, $\mathrm{K}$ and $\mathrm{Cu}$ lead to the formation of $\mathrm{FeC}_{x}$ structures with higher specific surface area and smaller size. A consequence of their smaller size is their more complete carburization, which is not the direct cause of the higher FTS rates observed in the presence of $\mathrm{K}$ and/or $\mathrm{Cu}$. Their more complete carburization reflects the shorter diffusion paths for lattice oxygen species in the smaller crystallites, but the attainment of steadystate FTS rates appears to require only the formation of $\mathrm{FeC}_{x}$ near surface layers, the FTS activity of which does not depend

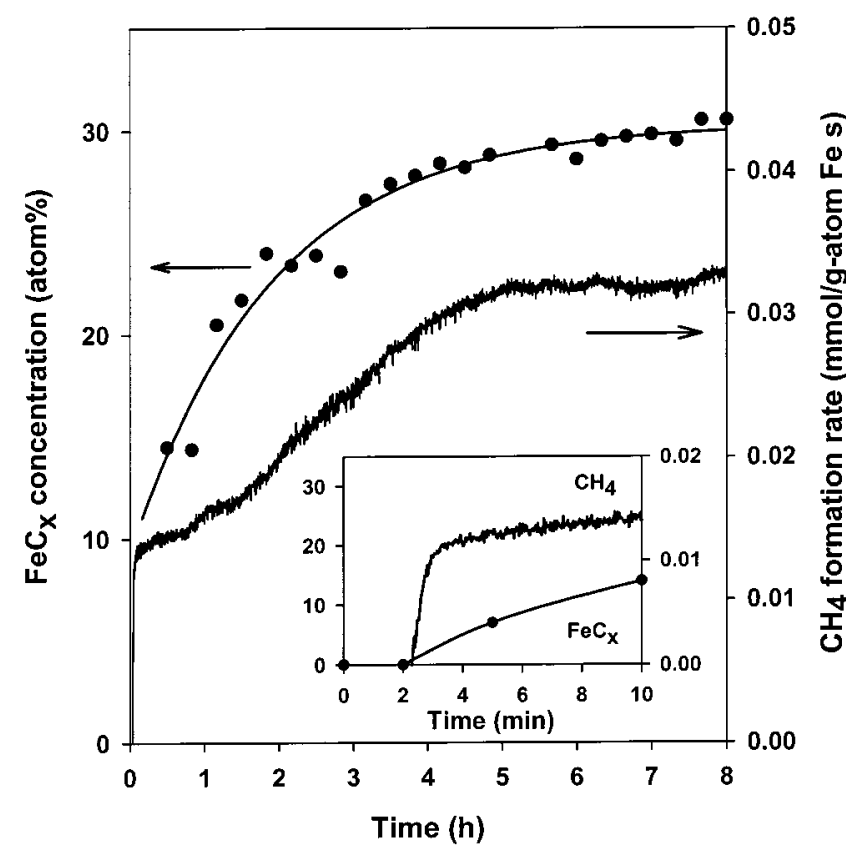

Figure 10. Fe carbide concentration (dots) obtained from XAS $\left(\mathrm{H}_{2} /\right.$ $\mathrm{CO}=2,523 \mathrm{~K}$, synthesis gas flow rate $=107 \mathrm{~mol} / \mathrm{g}$-atom Fe-h) and $\mathrm{CH}_{4}$ formation rate as a function of time on unpromoted precipitated $\mathrm{Fe}_{2} \mathrm{O}_{3}\left(\mathrm{H}_{2} / \mathrm{CO}=2,523 \mathrm{~K}\right.$, synthesis gas flow rate $=64.3 \mathrm{~mol} / \mathrm{g}$-atom $\mathrm{Fe}-\mathrm{h})$.

on the existence or chemical identity of a separate oxide phase residing within the carbide shell.

\section{Conclusions}

$\mathrm{Fe}_{2} \mathrm{O}_{3}$ FTS catalyst precursors sequentially reduce to $\mathrm{Fe}_{3} \mathrm{O}_{4}$ and then carburize to $\mathrm{FeC}_{x}$ in $\mathrm{CO}$ or $\mathrm{H}_{2} / \mathrm{CO}$ environments. The fast initial carburization of $\mathrm{Fe}_{3} \mathrm{O}_{4}$ becomes slower as diffusion of oxygen from the core to the surface through a dense carbide shell prevents the continuing carburization of the remaining oxide core. The nucleation of voids within the oxide core or the breakup of the carbide shell is required to accommodate the density mismatch between oxide and carbide phases. FTS rates increased proportionally with the extent of carburization and with the density of $\mathrm{CO}$ chemisorption sites in activated samples. This reflects the formation of smaller $\mathrm{FeC}_{x}$ structures when $\mathrm{Cu}$ or $\mathrm{K}$ cause the extensive nucleation of $\mathrm{FeC}_{x}$ structures during the activation of $\mathrm{Fe}_{2} \mathrm{O}_{3}$ precursors in $\mathrm{CO}$ or $\mathrm{H}_{2} / \mathrm{CO}$ mixtures. The initial reduction and carburization rates of $\mathrm{Fe}$ oxides are promoted by $\mathrm{Cu}$ and $\mathrm{K}$ because of their role in ratedetermining nucleation steps. The resulting larger number of nuclei leads to smaller $\mathrm{FeC}_{x}$ structures, to more complete carburization, and to a higher density of FTS active sites, which may contain a residual, but catalytically irrelevant, Fe oxide core. 
Acknowledgment. This work was supported by the U.S. Department of Energy (DOE) under contract number DE-FC2698FT40308. X-ray absorption data were collected at the Stanford Synchrotron Radiation Laboratory (SSRL), which is operated by the Department of Energy (DOE), Office of Basic Energy Sciences, under contract DE-ACO3-76SF00515.

\section{References and Notes}

(1) Storch, H. H.; Golumbic, N.; Anderson, R. B. The Fischer-Tropsch and Related Synthesis; John Wiley \& Sons: New York, 1951.

(2) Dry, M. E. In Catalysis: Science and Technology; Anderson, J.

R., Boudart, M., Eds.; Springer-Verlag: New York, 1981; Vol. 1, Chapter 4.

(3) Iglesia, E.; Reyes, S. C.; Madon, R. J.; Soled, S. L. Advances in Catalysis; Academic Press: New York, 1993; Vol. 39.

(4) Iglesia, E. Appl. Catal. A: General 1997, 161, 59.

(5) Dwyer, D. J.; Somorjai, G. A. J. Catal. 1978, 52, 291. 75,39

(6) Reymond, J. P.; Meriaudeau, P.; Teichner, S. J. J. Catal. 1982,

(7) Kuivila, C. S.; Stair, P. C.; Butt, J. B. J. Catal. 1989, 118, 299.

(8) Shultz, J. F.; Hall, W. K.; Dubs, T. A.; Anderson, R. B. J. Am. Chem. Soc. 1956, 28, 282.

(9) Dictor, R.; Bell, A. T. J. Catal. 1986, 97, 121.

(10) Rao, K. R. P. M.; Huggins, F. E.; Mahajan, V.; Huffman, G. P.; Rao, V. U. S.; Bhatt, B. L.; Bukur, D. B.; Davis, B. H.; O’Brien, R. J. Top. Catal. 1995, 2, 71.

(11) Mansker, L. D.; Jin, Y.; Burker, D. B.; Datye, A. K. Appl. Catal. A: General 1999, 186, 277.

(12) Amelse, J. A.; Butt, J. B.; Schwartz, L. H. J. Phys. Chem. B 1978, $82,558$.

(13) Lindner, U.; Papp, H. Appl. Surf. Sci. 1988, 31, 75.
(14) Shroff, M. D.; Kalakkad, D. S.; Coulter, K. E.; Kohler, S. D.; Harrington, M. S.; Jackson, N. B.; Sault, A. G.; Datye, A. K. J. Catal. 1995, 156, 185.

(15) Sayers, D. E.; Bunker, B. A. In X-ray Absorption: Principles, Applications, Techniques of EXAFS, SEXAFS and XANES; Koningsberger, D. C., Prins, R., Eds.; John Wiley and Sons: New York, 1988.

(16) Malinowski, E. R.; Howery, D. G. In Factor Analysis in Chemistry; John Wiley \& Sons: New York, 1981.

(17) Meitzner, G. D.; Huang, E. S. Fresenius J. Anal. Chem. 1992, 342, 61.

(18) Ernst, B.; Bensaddik, A.; Hilaire, L.; Chaumette, P.; Kiennemann, A. Catal. Today 1998, 39, 329.

(19) Clausen, B. S. Catal. Today 1998, 39, 293

(20) Anderson, R. B.; Hofer, L. J. E.; Cohn, E. M.; Steiner, H.; Greyson, M.; Weller, S. W.; In Catalysis; Emmett, P. H., Ed.; Reinhold: New York, 1956; Vol. 4.

(21) Li, S.; Li, A.; Krishnamoorthy, S.; Iglesia, E. To be submitted to J. Catal.

(22) Barton, D. G. Ph.D. Dissertation, University of California, Berkeley, 1998.

(23) Bearden, A.; Burr, A. F. Rev. Mod. Phys. 1967, 39, 125.

(24) WinXAS97 is an XAS data analysis program for PCs running MSWindows by Thorsten Ressler (http://ourworld.compuserve.com/homepages/ t_ressler).

(25) Li, S.; Krishnamoorthy, S.; Li, A.; Meitzner, G. D.; Iglesia, E. To be submitted to $J$. Catal.

(26) Köbel, H.; Ralek, M. Catal. Rev. Sci. Eng. 1980, 21, 225.

(27) Oyama, S. T.; Schlatter, J. C.; Metcalfe, J. E., III; Lambert, J. M., Jr. Ind. Eng. Chem. Res. 1988, 27, 1639.

(28) Kapoor, R.; Oyama, S. T. J. Mater. Res. 1997, 12, 471.

(29) Lide, D. R., Frederikse, H. P. R., Ed. Handbook of Chemistry and Physics, 75th ed.; The Chemical Rubber Co. Press: Boca Raton, FL, 1994

(30) Kung, H. H. Transition Metal Oxides: Surface Chemistry and Catalysis. In Studies in Surface Science and Catalysis; Kung, H. H., Ed.; Elsevier: New York, 1989; Vol. 45. 